\title{
Trade of threatened vultures and other raptors for fetish and bushmeat in West and Central Africa
}

\author{
R. Buij, G. Nikolaus, R. Whytock, D. J. Ingram and D. Ogada
}

\begin{abstract}
Diurnal raptors have declined significantly in western Africa since the 196os. To evaluate the impact of traditional medicine and bushmeat trade on raptors, we examined carcasses offered at markets at 67 sites (1-80 stands per site) in 12 countries in western Africa during 1990-2013. Black kite Milvus migrans and hooded vulture Necrosyrtes monachus together accounted for $41 \%$ of 2,646 carcasses comprising 52 species. Twenty-seven percent of carcasses were of species categorized as Near Threatened, Vulnerable or Endangered on the IUCN Red List. Common species were traded more frequently than rarer species, as were species with frequent scavenging behaviour (vs non-scavenging), generalist or savannah habitat use (vs forest), and an Afrotropical (vs Palearctic) breeding range. Large Afrotropical vultures were recorded in the highest absolute and relative numbers in Nigeria, whereas in Central Africa, palm-nut vultures Gypohierax angolensis were the most abundant vulture species. Estimates based on data extrapolation indicated that within West Africa $73 \%$ of carcasses were traded in Nigeria, $21 \%$ in Benin and $5 \%$ elsewhere. Offtake per annum in West Africa was estimated to be $975-1,462$ hooded vultures, 356-534 palm-nut vultures, 188-282 Rüppell's griffons Gyps rueppellii, 154-231 African white-backed vultures Gyps africanus, 143-214 lappet-faced vultures Torgos tracheliotos, and 40-60 crowned eagles Stephanoaetus coronatus. This represents a sizeable proportion of regional populations, suggesting that trade is likely to be contributing significantly to declines. Stronger commitment is needed, especially by governments in Nigeria and Benin, to halt the trade in threatened raptors and prevent their extirpation.
\end{abstract}

Keywords Bushmeat, commercial trade, diurnal raptors, traditional medicine, vultures, West and Central Africa

To view supplementary material for this article, please visit http://dx.doi.org/10.1017/So030605315000514

R. BUIJ (Corresponding author) Alterra, Wageningen University and Research Centre, PO Box 47, 6700 AA Wageningen, The Netherlands

E-mail ralph.buij@wur.nl

G. NiKolaus Feldweg 87, Cuxhaven, Germany

R. Wнутоск School of Biological and Environmental Sciences, University of Stirling, UK

D. J. InGRam School of Life Sciences, University of Sussex, Brighton, UK

D. OGADA* The Peregrine Fund, Boise, Idaho, USA

${ }^{*}$ Also at: National Museums of Kenya, Ornithology Section, Nairobi, Kenya

Received 12 August 2014. Revision requested 19 December 2014.

Accepted 13 April 2015. First published online 14 August 2015.

\section{Introduction}

Wildlife is exploited throughout West and Central Africa (Martin, 1991). The trade in bushmeat (wildsourced meat) has been recognized as having a negative impact on wildlife populations in forests and savannahs (Njiforti, 1996; Fa et al., 2002; Lindsey et al., 2013), and it is estimated $>1$ billion $\mathrm{kg}$ of wild animal meat is traded annually in Central Africa (Wilkie \& Carpenter, 1999). In addition to being exploited for bushmeat, many animals are hunted and traded specifically for use in traditional medicine, also known as wudu, juju or fetish (Adeola, 1992). The use of wildlife items for the treatment of a range of physical and mental diseases, or to bring good fortune, has been reported in almost every country in West and Central Africa. Birds, mammals, reptiles and other taxa are sold at specialized fetish markets. However, many species are sold for fetish alongside those sold for their meat, or they are sold for either purpose, suggesting that the traditional medicine and bushmeat trades are probably integrated and to some extent interdependent (Saidu \& Buij, 2013; Williams et al., 2014). In urban settings the commercial trade in wildlife-based medicinal products is often concentrated in traditional markets, where various animals, including threatened species, are offered openly for sale. In a few countries such practices have become uncommon, but in Burkina Faso and Benin they represent a strong cultural tradition that is supported by the governments of these countries (Nikolaus, 2011).

The commercialization of biological resources often has important conservation implications for heavily exploited species, especially those under pressure from other anthropogenic factors, such as habitat loss (Alves et al., 2013). This is the case in many parts of West and Central Africa, where human population densities and growth rates are high, even by sub-Saharan African standards. Increases in human populations contribute to high rates of land-use change and exploitation of wildlife, which also occurs frequently in protected areas in these regions (Brashares et al., 2004; Newmark, 2008). Large, long-lived apex predators with low productivity and slow maturation rates, such as large raptors, are especially vulnerable to increases in mortality rates, which can have a significant impact on population viability (Sæther \& Bakke, 2000). Given such vulnerability, increasingly intense persecution and hunting pressure related to commercial trade was suggested as one of the major drivers of the widespread decline of vultures (i.e. Rüppell's Gyps rueppellii, white-backed Gyps africanus, lappet-faced Torgos tracheliotus, white-headed 


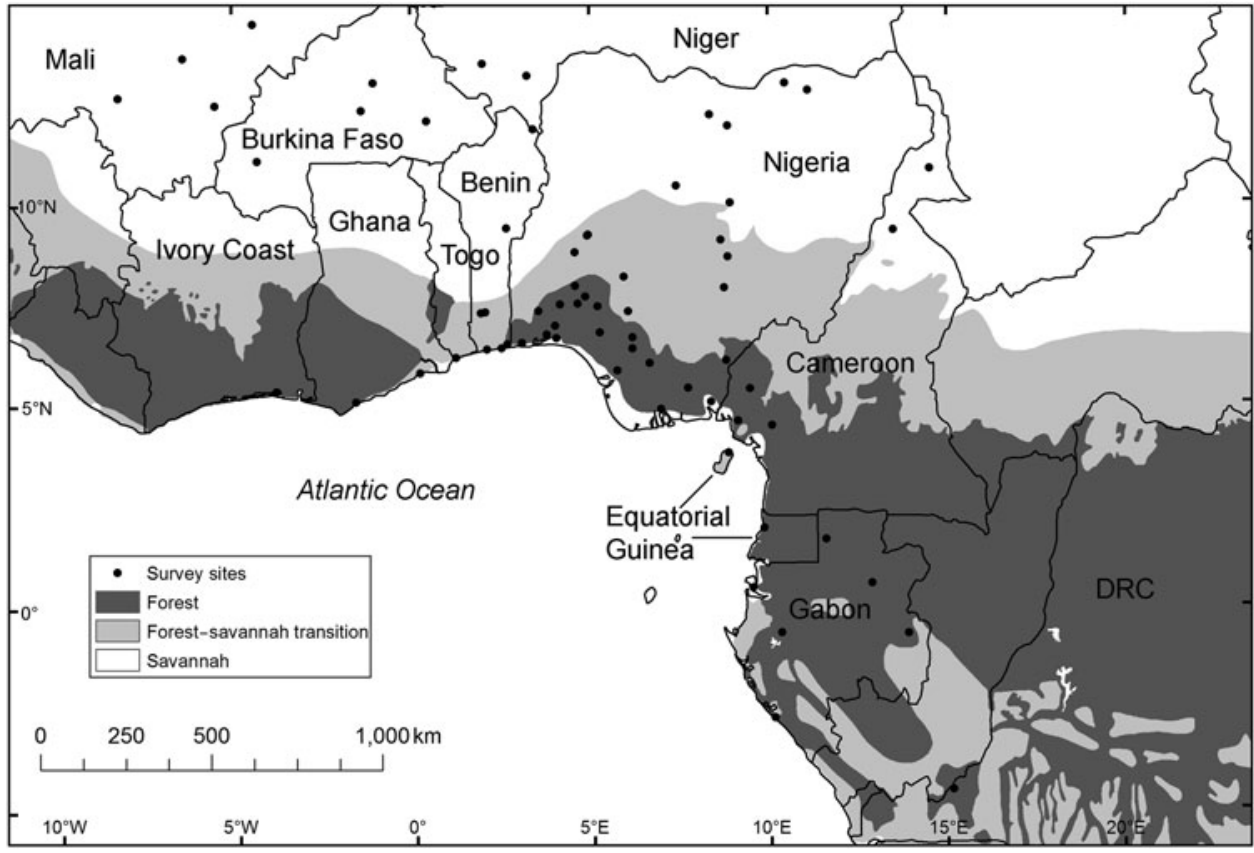

FIG. 1 Locations of the 67 markets in West and Central Africa where surveys of raptor carcasses for sale were conducted during 1990-2013 (Supplementary Table S1). Biomes are based on White (1983).
Trigonoceps occipitalis, and hooded vultures Necrosyrtes monachus) in the savannah biome during 1969-2004 (Thiollay, 2001, 2006; Rondeau \& Thiollay, 2004). Although a variety of techniques are used to kill vultures and other raptors for traditional medicine and consumption (Buij \& Croes, 2014), the use of poisoned baits is probably the most widespread method, often killing many vultures in a single location (Mander et al., 2007; Saidu \& Buij, 2013).

We evaluated the potential impact of the traditional medicine and commercial bushmeat trades on raptor populations in West and Central Africa, based on counts of raptor carcasses offered for sale at market stands. We assessed the composition of raptor carcasses offered for sale, and investigated the relationship between the numbers sold and morphological and ecological characteristics of the species identified. Our results were used to determine which species are most likely to be vulnerable to the trade and in which regions and countries. Based on previous studies we expected some taxa (e.g. vultures) and heavier-bodied species to be represented at markets more frequently than other species (Nikolaus, 2011; Williams et al., 2014). We also predicted that a species' migratory status would influence its trade numbers. AfroPalearctic migrants spend 6-8 months of the year at northern latitudes (with the exception of over-summering individuals of some species) and were expected to be represented less commonly than Afrotropical resident species (i.e. those that are present year-round in the region), including intra-African migrants. Controlling for species' abundance, we expected scavengers and savannah species to be recorded more frequently than non-scavengers and forest species, which are assumed to be harder to kill (i.e. poison) and detect, respectively. As vultures are known to be an important component of traditional medicine in the region, we determined the overall contribution of vultures to the total number of raptor carcasses recorded, and examined temporal changes therein. We also evaluated changes in the proportion of black kites Milvus migrans among carcasses, because these relatively common raptors are used regularly as substitutes for vultures by fetish traders, who pluck feathers from the kites' heads so that they resemble hooded vultures (Nikolaus, 2011). Vultures have become rare, and their parts more expensive, and therefore we expected that the contribution of black kites to carcass counts might have increased over the years. We estimated the numbers of raptors traded per annum, to assess the potential impact of the regional trade on threatened populations.

\section{Methods}

\section{Market inventories}

Carcass counts were conducted at fetish and bushmeat markets in the following countries throughout West and Central Africa (Fig. 1): Benin, Burkina Faso, Cameroon, Democratic Republic of the Congo, Equatorial Guinea, Gabon, Ghana, Ivory Coast, Mali, Niger, Nigeria and Togo. These included our own counts conducted at intervals of one year or more during 1999-2013 in eight West African countries and three Central African countries (Supplementary Table S1). Our data were supplemented by published and unpublished reports of raptor carcasses recorded during surveys of bushmeat markets in Cameroon, Equatorial Guinea and Gabon during 1990-2010. The latter counts were gathered from the 
bushmeat database of the OFFTAKE project (OFFTAKE, 2014), a collaborative project that collates datasets that quantify the offtake of terrestrial species (e.g. from subsistence hunting, medicinal use, trophy hunting). Datasets for the OFFTAKE database were gathered by searching the literature and contacting authors to request their raw data. Our surveys covered mostly fetish markets in West Africa and commercial bushmeat markets in Central Africa. Stands were visited throughout the year, covering the northern winter and summer periods as well as the local dry and wet seasons (Supplementary Table S1). Individual stands were surveyed only once per year. A proportion of the same stands were revisited in different years, although relocation of stands and changes in ownership and stand numbers made it difficult to track individual stands throughout the study period. For the same reason, the number of stands visited each year varied (Supplementary Table S1). Countries with larger, more numerous wildlife markets (e.g. Benin, Nigeria) were visited more often and covered more extensively than countries where the trade was limited (e.g. Ghana, Togo). The markets surveyed were in villages and towns distributed over a wide geographical area and were approximately equally distributed among forest ( $\mathrm{n}=34$ locations) and savannah, and forest-savannah transition biomes ( $n=33$; Fig. 1 ), thus minimizing any site (i.e. habitat) effect on species composition of the overall sample. Some markets were visited more often than others, however, and the largest markets in Benin and Nigeria in particular were located near or in the forest biome. In some countries, such as Nigeria, only a proportion of wellknown markets were visited, whereas most or all known markets were visited in other West African countries. Local interpreters assisted in locating markets and checking stalls. Carcasses were enumerated by observing and counting each raptor on display. Some birds were represented by entire carcasses, others merely by their heads; both are referred to here as representing a carcass.

\section{Trade per country and region}

The proportion of hooded and palm-nut vultures Gypohierax angolensis, large-bodied (i.e. $>_{3} \mathrm{~kg}$ ) Afrotropical vultures, black kites and other diurnal raptors among total carcass counts was calculated, to evaluate differences between countries (those with the largest markets: Nigeria, Benin) and regions (West and Central Africa). We treated palm-nut and hooded vultures separately because they are both known to be commonly traded (Nikolaus, 2011); the first is a largely frugivorous, not uncommon vulture of wet savannahs and forests, and the second is a locally common scavenger of livestock carcasses, waste, faeces and other anthropogenic offal in and around settlements. Large Afrotropical vultures (Rüppell's, lappet-faced, white-backed, and white-headed vultures) were considered separately because they are particularly highly valued by fetish traders and have undergone the greatest declines in the region (Thiollay, 2006). Black kites were considered separately because they are among the most common raptors in the fetish trade and are known to be sold as substitutes for vultures. We also evaluated changes in the proportional contribution of black kites and hooded, palm-nut and large Afrotropical vultures among cumulative counts of raptor carcasses in all West African markets during 1999-2013. Relative abundance of carcasses, rather than total counts, was evaluated because survey effort and recorded trade volumes varied between years. We used standard linear regression to investigate whether the proportions of these raptors in counts varied between years. As necessary, data were $\log 10$-transformed to meet the criteria of normality and homogeneity of variance.

\section{Characteristics of traded raptors}

Covariate modelling was used to evaluate predictions that total carcass counts for each species (i.e. the cumulative number of complete skins or heads counted) increased with species' abundance and body mass, and varied according to main habitat, scavenging behaviour, phylogenetic position and migratory status. The abundance of each species was taken from the most authoritative field guide for western Africa, from Mauritania in the north-west to Congo in the south-east (i.e. overlapping with the study area and period of the study; Borrow \& Demey, 2001). Species were categorized according to their abundance, as follows: scarce (encountered only irregularly, and infrequently to rarely within its normal habitat), uncommon (encountered relatively frequently but not regularly within its normal habitat), not uncommon (usually, but not invariably, encountered within its normal habitat), common (or locally common; invariably encountered singly or in significant numbers within its normal habitat, sometimes only locally). Information on the main habitat (i.e. most commonly found (year-round): savannah, forest or both), migratory status and mean body mass was also taken from the literature (Del Hoyo et al., 1994; Borrow \& Demey, 2001; Ferguson-Lees \& Christie, 2001). Egyptian vulture Neophron percnopterus, peregrine falcon Falco peregrinus and common kestrel Falco tinnunculus have Afrotropical and Palearctic breeding ranges and were considered AfroPalearctic migrants based on the breeding range of the majority of individuals in West Africa (Thiollay, 1977). Because black kites were mostly yellow-billed kites (i.e. the Afrotropical race aegyptius, which outnumbers the Palearctic race migrans in most of West and Central Africa, apart from in the far west), the species was considered an Afrotropical resident. Body mass was averaged for adult males and females. With regard to scavenging behaviour, species were categorized based on available information 
TABLE 1 Explanatory variables used to examine the number of carcasses per species of raptors sold for fetish or bushmeat in markets in West and Central Africa (Fig. 1) during 1990-2013.

\begin{tabular}{ll}
\hline Covariate & Description \\
\hline Abundance & Common, not uncommon, uncommon, scarce \\
Habitat & Savannah, savannah \& forest, forest \\
Functional group A & Non-scavenger, frequent scavenger, obligate scavenger \\
Functional group B & Non-scavenger, scavenger \\
Functional group C & Obligate scavenger, other \\
Migratory status & Afro-Palearctic migrant, Afrotropical resident \\
Body mass & Mean body mass (kg) of adults \\
Phylogeny & GYPINA Old World vultures (Aegypius, Gyps, Necrosyrtes, Torgos, Trigonoceps); ACCIPITRINA \\
& booted and hawk eagles, sparrowhawks, chanting goshawks, harriers, African fish eagle, black kite, \\
& buzzards, bat hawk (Aquila, Hieraaetus, Lophaetus, Polemaetus, Stephanoaetus, Accipiter, Melierax, \\
& Micronisus, Circus, Haliaeetus, Milvus, Buteo, Butastur, Kaupifalco, Macheiramphus); FALCONIDAE \\
falcons (Falco); GYPAETINI Pernine kites, gymnogene, Old World vultures (Aviceda, Pernis, \\
Polyboroides, Gypaetus, Neophron); CIRCAETINA snake eagles (Circaetus, Dryotriorchis); OTHER \\
elanine kites, secretary bird, osprey (Elanus, Chelictinia, Sagittarius, Pandion)
\end{tabular}

on their diet composition in sub-Saharan Africa (e.g. Brown \& Amadon, 1968; Steyn, 1982; Mundy et al., 1992; Ferguson-Lees \& Christie, 2001): non-scavenger (including species that scavenge only rarely or occasionally), frequent scavenger (scavenges frequently but also consumes a significant proportion of live prey; palm-nut and white-headed vultures, tawny eagle Aquila rapax, black kite, Eurasian marsh harrier Circus aeruginosus, bateleur Terathopius ecaudatus), and obligate or near-obligate scavenger (Rüppell's, lappet-faced, white-backed, hooded, Egyptian vultures). Unlike other Old World vultures the white-headed vulture was not categorized as an obligate scavenger because it is likely to consume live prey regularly (Murn, 2014). The Eurasian marsh harrier frequently scavenges in the European part of its winter range (e.g. Hiraldo et al., 1991) and this is also likely to be the case in the Sahel (Zwarts et al., 2009). We used results of phylogenetic analyses based on nuclear and mitochondrial DNA to classify raptor species into six groups (Lerner \& Mindell, 2005; Griffiths et al., 2007; Table 1).

We used generalized linear models with a negative binomial distribution and log link function using the package MASS in $R$ v. 3.o.2. (R Development Core Team, 2014) to model how explanatory variables describing the various species characteristics (Table 1) affected total carcass counts per species, summed across all the data, including across years and across all sites. Habitat, functional group, phylogeny and status were included as categorical variables, abundance as an ordinal variable and body mass as a continuous variable. We explored three sets of models, each consisting of all possible subsets of combinations of explanatory variables, including one of three explanatory variables for functional group (Table 1). By including three subdivisions for the functional group variable in each model set, we examined the relative support for each of three alternative hypotheses: that species carcass counts are best explained by (1) an increasing frequency of scavenging, from non-scavenger, to frequent, to obligate scavenger, (2) frequent scavenging (i.e. without differentiation between obligate and frequent scavengers), or (3) obligate scavenging. Support for the latter would indicate that obligate scavenging drives carcass abundance patterns, whereas support for the second subdivision would suggest that abundance patterns were driven by frequent scavenging. We used the corrected Akaike information criterion (AICc) value to select the most parsimonious models (those that fit the data best with the fewest parameters; i.e. with the lowest AICc; Burnham \& Anderson, 2002), and the top four $\triangle \mathrm{AICc}$ of models as the cut-off criterion for delineating a set of top models. We computed model-averaged parameters by averaging over all models in the set of top models. We used the dredge function in $R$ (part of the package MuMIn v. 1.9.5; Bartoń, 2013) to implement a model-averaging approach for the top models to make robust parameter estimates and predictions (Johnson \& Omland, 2004), and estimated the relative importance of each variable, based on the sum of Akaike weights. We subsequently evaluated the effect of variables based on overlap of the $95 \%$ confidence intervals (following Burnham \& Anderson, 2002).

\section{Total numbers involved in the trade}

To determine the potential impact of the trade on raptor populations, we estimated the number of raptors traded annually at West African markets during 2008-2013, using extrapolation of mean counts per market stand and known carcass turn-over rates. These estimates were based on carcass counts at 416 stands visited in 2008, 166 stands in 2009, 121 stands in 2010, 78 stands in 2011, and 71 stands in 2013, in Benin, Nigeria, Mali and Burkina Faso. Because species composition varied between Nigeria and Benin we calculated mean counts per stand separately for these and the remaining countries, and extrapolated to the estimated total number of stands. In Nigeria we visited approximately 
one-third of the market stands trading in animal parts in 2008, and therefore we tripled the number of stands to derive a country-wide estimate of 960 stands. We estimated a total of 200 stands for Benin and 100 for the remaining West African countries where surveys had been conducted. We cautiously estimated the minimum and maximum numbers traded based on turnover rates of two to three birds per stand per year, although detailed examinations for various species suggest that this turnover rate can be higher (3-8 or more carcasses per year; Cocker, 2000; Nikolaus, 2001; Awoyemi, 2014; G. Nikolaus, unpubl. data).

\section{Results}

\section{Trade per country and region}

Black kite and hooded vulture together represented $41 \%$ of a total 2,646 raptor carcasses of 52 species recorded at markets in West and Central Africa (Supplementary Table S2). Shikra Accipiter badius was the most commonly traded small raptor, comprising $7.8 \%$ of the total carcass count. AfroPalearctic migrants together represented $6.4 \%$ of carcass counts. This is assuming that short-toed Circaetus gallicus and Beaudouin's snake eagle Circaetus beaudouini carcasses were divided equally between species, and excluding the (likely) possibility that the Palearctic race migrans of black kite comprised a small proportion of black kite carcasses. The most common Afro-Palearctic migrant among carcasses was the Eurasian marsh harrier. Palm-nut and Rüppell's were the most commonly recorded vultures, after the hooded vulture. However, the contribution of vultures to total carcass counts varied between countries and regions (Fig. 2); whereas the greatest proportion and diversity of large Afrotropical vultures (Rüppell's, white-backed, white-headed, lappet-faced vultures) were recorded in Nigeria ( $14 \% ; n=957$ carcasses), relatively few were offered for sale elsewhere in West Africa $(3.1 \% ; n=1,587)$. In Central Africa palm-nut vulture carcasses were recorded most commonly ( $53 \%$ of total counts; $n=102$ carcasses), contrary to the situation in West African countries (o- $9 \%$ of carcasses). Overall, $27 \%$ of carcasses on offer were of species categorized as threatened (Near Threatened to Endangered) on the IUCN Red List of Threatened Species (IUCN, 2015). Of these $(n=712), 50 \%$ were found in Nigeria and $29 \%$ in Benin. Nigeria was the only country where the regionally threatened martial eagle Polemaetus bellicosus and secretary bird Sagittarius serpentarius were recorded at markets (Supplementary Table S2). Despite more than half of markets, including some of the largest markets, being located in the forest biome, $80 \%$ of carcasses were of species mainly associated with savannah habitats, suggesting that raptors are transported significant distances to commercial markets.

The data did not indicate a significant increase in the proportional contribution of black kites to total carcass counts

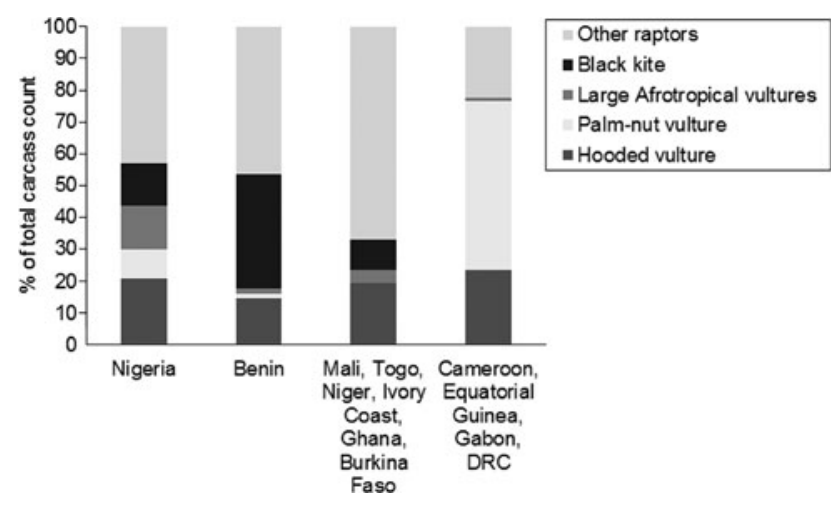

FIg. 2 Percentages of black kites Milvus migrans, large Afrotropical vultures (Rüppell's Gyps rueppellii, lappet-faced Torgos tracheliotos, white-backed Gyps africanus, and white-headed vultures Trigonoceps occipitalis), palm-nut Gypohierax angolensis and hooded vultures Necrosyrtes monachus, and other raptors among raptor carcasses recorded at markets in Nigeria $(n=957$ carcasses), Benin $(n=1,225)$, Mali, Togo, Niger, Ivory Coast, Ghana and Burkina Faso $(\mathrm{n}=362)$, and Cameroon, Equatorial Guinea, Gabon and DRC $(n=102)$ during 1999-2013.

during 1999-2013 (linear regression: $F_{1,7}=2.92$, $\beta=1.62 \pm \mathrm{SE} 0.95, \mathrm{P}=0.13$, adjusted $R^{2}=0.19$ ). However, surveys in 2011 may not have yielded a representative sample because a relatively small number of carcasses was recorded $(\mathrm{n}=94)$ compared to other years $(\mathrm{n}=124-804)$. Excluding 2011 from the analysis, a significant proportional increase of black kites over the years was apparent (linear regression: $F_{1,6}=7.64, \beta=2.22 \pm \mathrm{SE} 0.80, \mathrm{P}=0.03$, adjusted $R^{2}=0.49$; Fig. 3), providing support for the idea that black kites have been traded increasingly since the late 1990s. No significant temporal trend was detected in the proportion of large Afrotropical $\left(F_{1,6}=0.62, \beta=-0.36 \pm \mathrm{SE} 0.45, \mathrm{P}=0.46\right.$, adjusted $R^{2}=-0.057$ ), palm-nut (linear regression on $\log$ 10-transformed data: $F_{1,6}=0.65, \beta=-0.025 \pm \mathrm{SE} 0.031$, $\mathrm{P}=0.45$, adjusted $\left.R^{2}=-0.05\right)$ or hooded vultures $\left(F_{1,6}=0.47\right.$, $\beta=-0.33 \pm \mathrm{SE} 0.49, \mathrm{P}=0.52$, adjusted $\left.R^{2}=-0.08\right)$ among raptor carcasses.

\section{Characteristics of traded raptors}

Our models found strong support for an influence of species' abundance, habitat, migratory status, and scavenging behaviour on carcass counts. All six plausible models (i.e. models with $\Delta$ AICc $<4$ of the top model; Table 2) included the influence of species' abundance and scavenging behaviour, and five and four of the six top models featured habitat and migratory status, respectively. Body mass was represented once in the top model set, and phylogeny and functional group $\mathrm{C}$ were not included. The four most important predictors among the six plausible models, in decreasing order of importance, were species' abundance (relative importance: 1), habitat (0.90), functional group B (0.83), and 


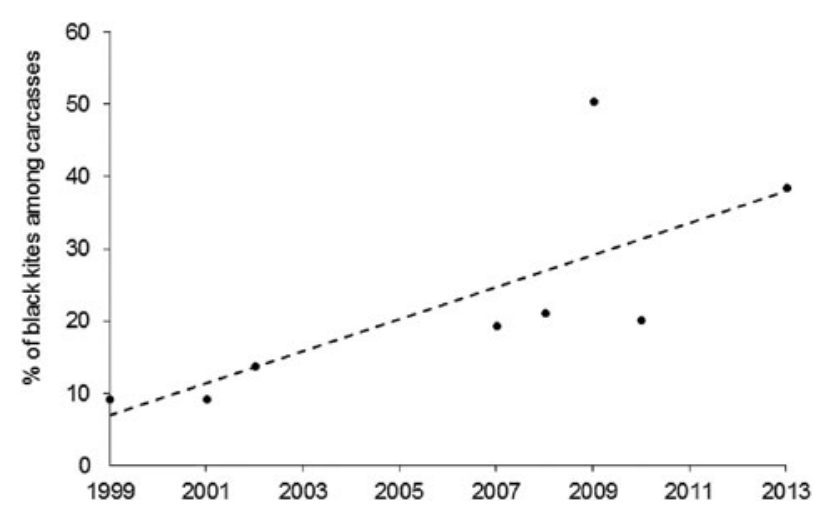

FIG. 3 Linear regression model of the relationship between the percentage of black kites among raptor carcasses at markets in West and Central Africa (Fig. 1) and year of survey, during 1999-2013.

status (0.72; Table 3). The model-averaged parameters of the top models (Table 3) strongly supported the hypothesis that more common species were represented more often among carcasses than scarcer species. Forest species were less likely to be found in markets than savannah species, or habitat generalists that inhabit both savannah and forests (Fig. 4). Scavenging behaviour increased the probability of being traded compared to non-scavenging (Fig. 4) but there was little support for the idea that obligate scavenging alone was responsible for this pattern (functional group C featured only twice among models with AICc weights $\geq 1 \%$; Table 2). Rather, our results strongly suggest that all species that scavenge frequently (i.e. frequent and obligate scavengers) are traded more commonly than those that consume carrion only rarely or occasionally (Table 3 ). Species with an Afrotropical breeding range were more likely to be traded compared to those with a Palearctic breeding range (Fig. 4). Although body mass featured in the top model set (relative importance: 0.10; Table 3), the confidence intervals of the body mass predictor included zero, suggesting species' body mass did not influence carcass counts.

\section{Total numbers involved in trade}

In West Africa during 2008-2013 an estimated 4,214-6,321 raptors were traded each year, based on extrapolated carcass count data (Supplementary Table $\mathrm{S}_{3}$ ). An estimated 9031,355 raptors were traded each year in Benin, 3,084-4,626 in Nigeria, and 226-345 in the rest of West Africa (Supplementary Table $\mathrm{S}_{3}$ ). The bulk of the trade was in Nigeria ( $73 \%$ of carcasses), with $21 \%$ in Benin and $5 \%$ elsewhere in West Africa. Assuming turn-over rates of 2-3 individuals per stand per year, an estimated 5,850-8,772 hooded vultures and 5,232-7,848 black kites were traded during the 6-year period in West Africa. Estimates for other commonly traded large raptors during this period were 2,136-3,204 palm-nut vultures, 1,128-1,692 Rüppell's vultures,
924-1,386 white-backed vultures, 858-1,284 lappet-faced vultures, and 240-360 crowned eagles Stephanoaetus coronatus. For $77-81 \%$ of species $(n=47)<100$ individuals are estimated to be traded annually in West Africa.

\section{Discussion}

The diversity of raptor species, and number of individuals, offered at West and Central African markets, particularly in Nigeria and Benin, is considerable. Approximately $70 \%$ of the region's diurnal raptor species were on sale, suggesting that many raptors are used as fetish species (Nikolaus, 2001, 2011; Williams et al., 2014) as well as bushmeat (Saidu \& Buij, 2013; Buij \& Croes, 2014; Whytock et al., 2014).

Our results indicate that Nigeria and Benin are important drivers of the regional trade in raptors in West Africa. This supports an earlier assertion by Nikolaus (2011) that there is a high per capita use of raptors for fetish in Nigeria and Benin. Fetish demand and prices of vultures are particularly high in Nigeria (Nikolaus, 2011), where large Afrotropical vultures constituted a greater proportion of raptors traded compared to Benin or elsewhere in West and Central Africa. Large Afrotropical vultures were already largely extirpated in Nigeria in the early 1990s (Nikolaus, 2001), and human-commensal hooded vultures have declined (Ogada \& Buij, 2011). The diversity and number of vultures for sale in Nigeria support anecdotal evidence and results of questionnaire surveys indicating that the catchment area for Nigerian traders extends at least from Burkina Faso to Chad (Nikolaus, 2011; Saidu \& Buij, 2013). Because large Afrotropical vultures or their eggs are valued at several months' salary, Nigerian poachers invest in obtaining them, sourcing them from countries in the wider region (Saidu \& Buij, 2013). Shifts in pressure to other species, such as migratory black kites, suggest that the trade has the potential to affect raptor populations beyond West and Central Africa.

For many West and Central African raptors the impact of the trade may be limited compared to other anthropogenic and climate-related factors that influence their food resources, nest availability, and population dynamics (e.g. Buij et al., 2013a,b). The commercial trade, however, can be implicated in the decline of vultures and other large raptors in the region. For some species, such as Rüppell's, hooded, white-backed, white-headed, and lappet-faced vultures, the numbers traded probably represent a significant proportion of their regional populations. Although rigorous population estimates are unavailable for most species, the extrapolated annual toll of lappet-faced vultures in West Africa during 2008-2013 represents as much as $4.8-7.1 \%$ of c. 3,000 individuals estimated to have occurred in West Africa and the Sahara during the 1990s (Shimelis et al., 2005), assuming they were all sourced from this region. However, trade 
TABLE 2 Top generalized linear models (Akaike weight $>1 \%$ ) examining the relationship between cumulative carcass counts of 52 raptor species (Supplementary Table S2; $\mathrm{n}=2,646$ carcasses) at markets in 12 countries in West and Central Africa during 1990-2013 (Fig. 1) and the species' abundance, habitat, functional group, phylogenetic position, body mass, and migratory status (Table 1), with degrees of freedom, corrected Akaike information criterion (AICc), $\triangle \mathrm{AICc}$ and Akaike weight.

\begin{tabular}{|c|c|c|c|c|}
\hline Model $^{1}$ & df & $\mathrm{AICc}$ & $\triangle \mathrm{AICc}$ & Akaike weight ${ }^{2}$ \\
\hline Abundance + habitat + functional group $\mathrm{B}+$ status & 9 & 434.51 & 0.00 & 0.31 \\
\hline Abundance + habitat + functional group $\mathrm{B}$ & 8 & 435.91 & 1.39 & 0.15 \\
\hline Abundance + functional group B + status & 7 & 437.32 & 2.81 & 0.08 \\
\hline Abundance + habitat + functional group A + status & 10 & 437.39 & 2.88 & 0.07 \\
\hline Abundance + habitat + functional group $B+$ body mass + status & 10 & 437.45 & 2.94 & 0.07 \\
\hline Abundance + habitat + functional group A & 9 & 438.22 & 3.70 & 0.05 \\
\hline Abundance + habitat + functional group $B+$ body mass & 9 & 438.78 & 4.27 & 0.04 \\
\hline Abundance + functional group B + body mass + status & 8 & 439.29 & 4.78 & 0.03 \\
\hline Abundance + functional group B & 6 & 439.79 & 5.27 & 0.02 \\
\hline Abundance + habitat + functional group $\mathrm{A}+$ body mass + status & 11 & 439.88 & 5.37 & 0.02 \\
\hline Abundance + functional group A + status & 8 & 440.11 & 5.60 & 0.02 \\
\hline Abundance + habitat + functional group $\mathrm{C}+$ status & 9 & 440.16 & 5.64 & 0.02 \\
\hline Abundance + habitat + functional group $\mathrm{C}$ & 8 & 440.28 & 5.76 & 0.02 \\
\hline Abundance + habitat + functional group $B+$ status + phylogeny & 14 & 441.12 & 6.61 & 0.01 \\
\hline Abundance + habitat + functional group $\mathrm{A}+$ body mass & 10 & 441.17 & 6.65 & 0.01 \\
\hline Abundance + habitat + functional group $B+$ phylogeny & 13 & 441.23 & 6.72 & 0.01 \\
\hline Abundance + functional group A + body mass + status & 9 & 441.33 & 6.81 & 0.01 \\
\hline Abundance + habitat + body mass & 8 & 442.00 & 7.49 & 0.01 \\
\hline Abundance + functional group A & 7 & 442.33 & 7.82 & 0.01 \\
\hline Abundance + functional group $B+$ body mass & 7 & 442.36 & 7.84 & 0.01 \\
\hline Abundance + habitat + body mass + status & 9 & 442.48 & 7.97 & 0.01 \\
\hline Abundance + habitat + status & 8 & 442.68 & 8.17 & 0.01 \\
\hline Null & 2 & 497.20 & 62.69 & 0.00 \\
\hline
\end{tabular}

${ }^{1}$ Listed in order of most to least parsimonious model, after fitting combinations of all possible subsets with each of the three explanatory variables for functional group.

${ }^{2}$ The weight of evidence in support of the model (cf. Burnham \& Anderson, 2002)

volumes may have constituted a higher proportion of populations remaining in 2008-2013, as was the case for the whiteheaded vulture. There were an estimated 1,000 or more white-headed vultures in West Africa in the 1990s (Mundy et al., 1992), and $2.4-3.6 \%$ of this number were channelled through the trade each year during 2008-2013. As the most recent estimate suggests that as few as 456 remained in 2014 (C. Murn, unpubl. data), the annual trade constituted $5.3-8 \%$ of the remaining West African population. Hooded vultures, which are under pressure from poachers, were estimated to number c. 144,000 individuals in West Africa (Ogada \& Buij, 2011). Our estimates suggest that $0.7-1 \%$ of those were lost to the trade annually during 2008-2013. Our estimates of annual tolls, even those based on more recent population estimates, are likely to be biased low because we used conservative estimates of turnover rates to estimate numbers traded; other studies suggest these may be significantly higher (e.g. Awoyemi, 2014). Although we lack quantitative data, the majority of raptors recorded at markets appeared to be adults, which have a vital role in population dynamics, especially for larger species (Sæther \& Bakke, 2000). Persecution may be one of the most important factors of non-natural mortality in threatened populations of large raptors, which may decline even with only a small decrease in adult survival rates (Whitfield et al., 2004; Oro et al., 2008; Ortega et al., 2009). Assuming the majority of vultures and other large raptors on offer at markets were killed specifically for trade, the trade probably contributed to increased mortality rates and significant population declines, including the $98 \%$ decline of large vultures outside protected areas in central West Africa during 1969-2004 (Thiollay, 2006).

The percentage of vultures among raptor carcasses was highest in Central Africa, mostly accounted for by palm-nut vultures. The palm-nut vulture is an important and valuable species for fetish purposes in West Africa, and individuals have been sold for c. USD 100 in Nigeria (Nikolaus, 2011). We estimated its offtake in West Africa to be 356-534 individuals per annum (i.e. $0.2 \%$ of the continental population of c. 240,000, most of which are in West and Central Africa; Mundy et al., 1992). However, the true impact of hunting on palm-nut vulture populations may remain largely concealed, at least in Central Africa, where the vultures are often consumed in bushmeat hunting camps rather than being transported to markets (Whytock et al., 2014). Although this highly prized species is categorized as Least Concern on the IUCN Red List (IUCN, 2015) because of 
TABLE 3 Effects of species characteristics assumed to influence cumulative carcass counts of 52 raptor species $(\mathrm{n}=2,646$ carcasses) at markets in 12 countries in West and Central Africa during 1990-2013 (Fig. 1), with model-averaged parameter estimates for each variable (Table 1) in the six most strongly supported models (Table 2), and the relative importance of explanatory variables.

\begin{tabular}{|c|c|c|}
\hline Variable & Parameter estimate ( $95 \% \mathrm{CI})$ & Relative importance $^{1}$ \\
\hline (Intercept) & $3.59(2.38-4.81)$ & \\
\hline \multicolumn{3}{|l|}{ Abundance $^{2}$} \\
\hline Not uncommon & $-1.35(-2.11--0.60)$ & 1.00 \\
\hline Uncommon & $-2.53(-3.22--1.84)$ & \\
\hline Scarce & $-3.50(-4.69--2.31)$ & \\
\hline \multicolumn{3}{|l|}{ Habitat $^{3}$} \\
\hline Savannah & $0.97(0.21-1.73)$ & 0.90 \\
\hline Savannah \& forest & $1.46(0.59-2.32)$ & \\
\hline \multicolumn{3}{|l|}{ Functional group $\mathrm{B}^{4}$} \\
\hline Scavenger & $0.95(0.38-1.52)$ & 0.83 \\
\hline \multicolumn{3}{|l|}{ Status ${ }^{5}$} \\
\hline Afrotropical resident & $0.66(0.07-1.25)$ & 0.72 \\
\hline \multicolumn{3}{|l|}{ Functional group $\mathrm{A}^{4}$} \\
\hline Frequent scavenger & $0.80(0.11-1.50)$ & 0.17 \\
\hline Obligate scavenger & $1.08(0.32-1.84)$ & \\
\hline Body mass & $-0.03(-0.19-0.13)$ & 0.10 \\
\hline $\begin{array}{l}{ }^{1} \text { Calculated by summing Ak } \\
\text { zero are indicated in bold. } \\
{ }^{2} \text { Reference group: common } \\
{ }^{3} \text { Reference group: forest } \\
{ }^{4} \text { Reference group: non-scave } \\
{ }^{5} \text { Reference group: Afro-Pale }\end{array}$ & del set (Burnham \& Anderson, 2002 & he estimate not overlappin \\
\hline
\end{tabular}

its large range, population size and apparently stable population, ongoing persecution warrants closer examination of its population trends.

Other large raptors vulnerable to persecution include Africa's largest eagles (martial and crowned). Extrapolation of the estimated annual toll suggests at least 240 crowned eagles were traded commercially in West Africa during 20082013, which represents an unknown but probably significant proportion of regional populations. Although these uncommon raptors are unlikely to be poisoned on a scale comparable to scavengers, they may be shot; crowned eagles may be lured by bushmeat hunters imitating the calls of prey animals (Whytock \& Morgan, 2010). This may occur more frequently than previously thought, as crowned eagles were the second most common forest species and the commonest large raptors (i.e. $>3 \mathrm{~kg}$ ) recorded at markets after Rüppell's, whitebacked and lappet-faced vultures. Their slow maturation rate and biennial reproduction in tropical forests make the crowned eagle one of the most vulnerable raptors to direct persecution (Shultz, 2002; Whitfield et al., 2004), compounding negative impacts of habitat loss and degradation, disturbance of nest sites, and prey depletion by bushmeat hunters (Lindsey et al., 2013; Whytock et al., 2014).

The positive relationship between species' abundance and carcass counts suggests that at a regional scale species are targeted indiscriminately to supply the trade. However, our results showed that Afrotropical habitat generalists inhabiting forests and savannahs, and those of savannah habitats, are particularly commonly traded, whereas trade in forest specialists is comparatively uncommon. This relative scarcity of forest-restricted species in the trade may be related to the difficulty in finding, shooting or poisoning these species, which are generally more elusive. The greater numbers of Afrotropical residents in the trade, including intra-African migrants, is probably related to their year-round availability; the majority of Afro-Palearctic migrants spend much of the year outside the poachers' catchment area.

Our models support the hypothesis that, together with obligate scavenging vultures, raptors that scavenge frequently are more likely to end up at markets compared to nonscavenging species. We suspect this is related to the ease of killing most scavengers using poisoned baits, which is probably the most widespread method used to kill raptors and other predator populations in sub-Saharan Africa (Ogada, 2014). Frequent use of human-dominated, lowquality habitats may increase the vulnerability to poisoning of some obligate and frequent scavengers (black kite, hooded vulture; Otieno et al., 2010; Kendall, 2013; Buij et al., 2013a). Some frequent scavengers (black kite, Eurasian marsh harrier) congregate at easily detectable roosts, possibly increasing their vulnerability to poachers; the high search efficiency of others (bateleur, tawny eagle; Kendall, 2013; Kane et al., 2014) may facilitate poisoning or trapping using baits. Alternatively, some frequent scavengers may constitute bycatch of poachers targeting more highly prized vultures. 

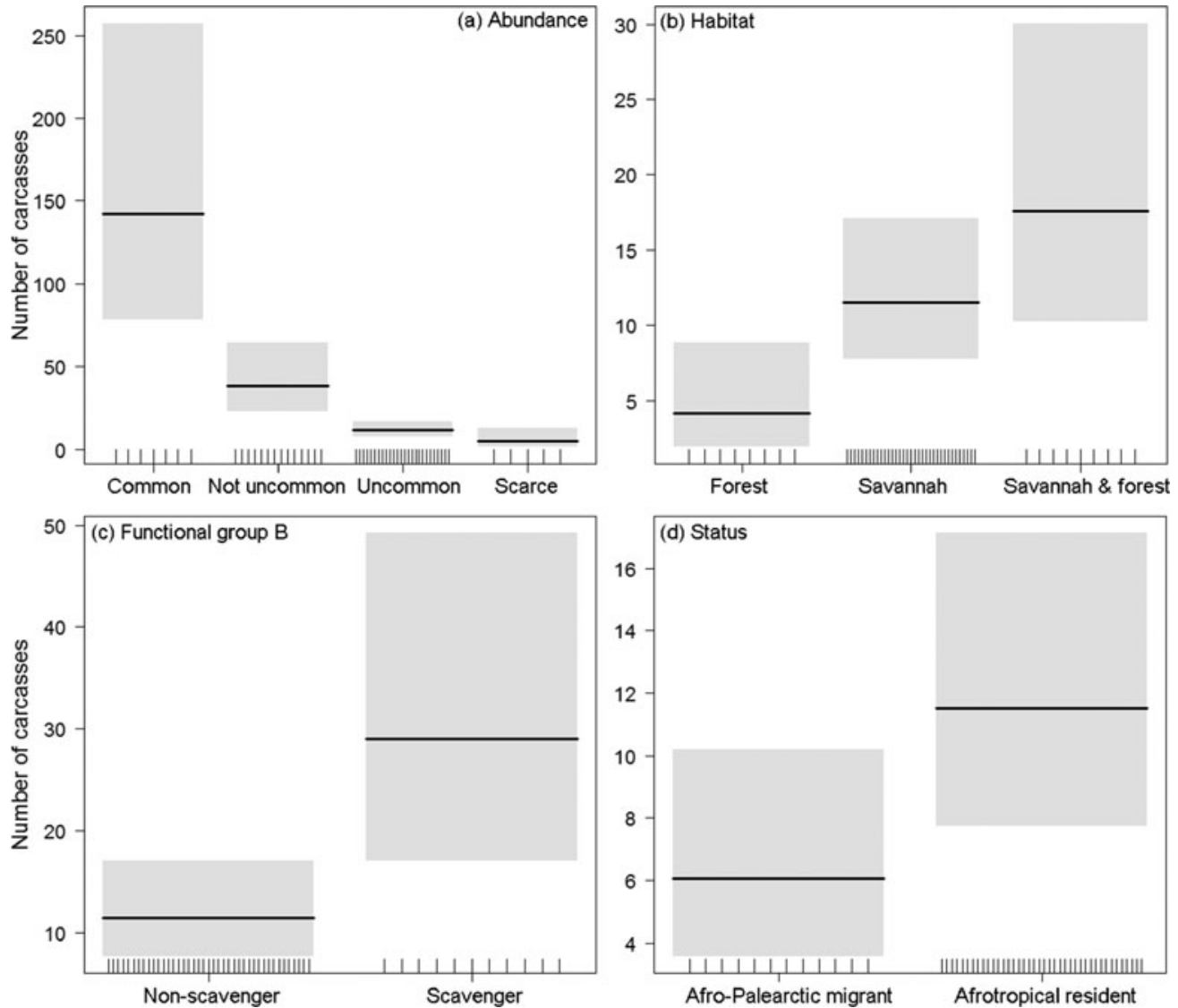

FIG. 4 Plots of the modeled relationship between carcass counts of raptor species and the species' (a) abundance, (b) habitat, (c) functional group B, and (d) status (Table 1), as estimated by the top model (cf. Table 3). Carcass counts are plotted on their original scale. The black horizontal line represents the model-predicted value, with all other variables set to their most common category, and the shaded areas indicate $95 \%$ confidence bands; the vertical ticks indicate number of observations.

It is possible that not all raptors recorded at markets were killed for trade; casualties related to other anthropogenic factors (e.g. electric power lines, roads, pesticides), or disease may also be sold in markets. However, indirect evidence suggests that mortalities related to these factors probably account for only a small proportion of raptors offered at markets. The electrical power transmission system over most areas in West and Central Africa is poorly developed, unlike in North and southern Africa, where this is a significant cause of mortality (Nikolaus, 2006; Jenkins et al., 2010). There are unlikely to be many raptor deaths caused by road traffic given the condition of most roads prevents driving at high speed, which is confirmed by generally few raptor carcasses found along roads (R. Buij, pers. obs.). Casualties from secondary pesticide poisoning also appear to be generally low, being significant only when colonies of red-billed quelea Quelea quelea are sprayed with fenthion when irruptions occur (Keith \& Bruggers, 1998). Deaths of hooded vultures as a result of avian influenza may be significant, at least locally as shown in Burkina Faso (Ducatez et al., 2007), but we are not aware of similar die-offs elsewhere in the region. We therefore assume that the majority of raptors on offer at markets are probably killed deliberately for the trade, which is supported by information obtained from traders in Nigeria (Saidu \& Buij, 2013).

The trade in raptors for traditional medicine or for food is likely to have contributed considerably to the significant decline of vultures and other large raptors, and possibly also to a number of smaller raptors, in West and Central Africa. Within West Africa, Benin and Nigeria collectively accounted for $95 \%$ of the carcasses traded during 2008-2013. Conservation efforts focused on these two countries would therefore have the most significant impact on curtailing this trade within the wider region. More than a quarter of raptors sold at the markets surveyed in West and Central Africa since 1990 are categorized as threatened on the IUCN Red List (IUCN, 2015), including five Afrotropical vultures that warrant uplisting to Critically Endangered on the basis of population decline (Ogada et al., 2015). A lack of population data makes it difficult to conduct accurate Red List assessments for some vulnerable species that are commonly exploited by the trade (palm-nut vulture, crowned eagle). Increasing prices are leading to increasing pressure on remaining vultures, as 
well as on species sold as vultures to unsuspecting consumers, notably black kites. The number of threatened species displayed openly in markets suggests that their declining population status is unknown or of little concern to those who enforce wildlife legislation, or those involved in the trade. In some countries efforts are made to enforce conservation legislation but a combination of corruption, lack of funding and lack of reliable information at various levels within government departments results in de facto impunity for traders. In other countries, such as Benin, the government supports the trade as part of the country's cultural heritage. There is a need for international action targeting suppliers, traders and consumers, initially focused on large markets in Nigeria and Benin, and for stronger commitments from governments to halt the trade in threatened raptors.

\section{Acknowledgements}

We thank two anonymous referees for their constructive comments. Unpublished data were provided by the University of Stirling African Forest Ecology Group, which works in Gabon under agreement with the Institute of Tropical Ecology Research.

\section{References}

Adeola, M.O. (1992) Importance of wild animals and their parts in the culture, religious festivals, and traditional medicine of Nigeria. Environmental Conservation, 19, 125-134.

Albrechtsen, L., Macdonald, D.W., Johnson, P.J., Castelo, R. \& FA, J.E. (2007) Faunal loss from bushmeat hunting: empirical evidence and policy implications in Bioko Island. Environmental Science \& Policy, 10, 654-667.

Alves, R.R.N., Rosa, I.L., Albuquerque, U.P. \& Cunningham, A.B. (2013) Medicine from the wild: an overview of the use and trade of animal products in traditional medicines. In Animals in Traditional Folk Medicine: Implications for Conservation (eds R.R.N. Alves \& I. L. Rosa), pp. 25-42. Springer, Berlin and Heidelberg, Germany.

Awoyemi, S. (2014) Vulture declines in West Africa: investigating the scale and (socioeconomic) drivers of the trade in vulture parts for traditional medicine. MPhil thesis. University of Cambridge, UK.

BARTOŃ, K. (2013) MuMIn: multi-model inference. $R$ v. 1.9.5. Http:// cran.r-project.org/web/packages/MuMIn/index.html [accessed 26 December 2014].

Borrow, N. \& Demey, R. (2001) Birds of Western Africa. Christopher Helm, London, UK.

Brashares, J.S., Arcese, P., Sam, M.K., Coppolillo, P.B., Sinclair, A.R. \& BAlmford, A. (2004) Bushmeat hunting, wildlife declines, and fish supply in West Africa. Science, 306, 1180-1183.

Brown, L.H. \& Amadon, D. (1968) Eagles, Hawks \& Falcons of the World. McGraw-Hill Book Company, New York, USA.

Buij, R. \& Croes, B.M. (2014) Raptors in northern Cameroon, December 2005-December 2010. ABC Bulletin, 21, 26-63.

Buij, R., Croes, B.M., Gort, G. \& Komdeur, J. (2013a) The role of breeding range, diet, mobility and body size in associations of raptor communities and land-use in a West African savanna. Biological Conservation, 166, 231-246.
Buij, R., Kortekaas, K., Van Krimpen, R.R.D., Van Wijk, R., Van Der Zanden, S., De Iongh, H.H. et al. (2013b) Breeding performance of the grasshopper buzzard (Butastur rufipennis) in a natural and a human-modified West African savanna. The Condor, $115,47-57$.

Burnham, K.P. \& Anderson, D.R. (2002) Model Selection and Multimodel Inference: A Practical Information-theoretic Approach. Springer Science \& Business Media, New York, USA.

Cocker, M. (200o) African birds in traditional magico-medicinal use-a preliminary survey. ABC Bulletin, 7, 60-65.

Del Hoyo, J., Elliott, A. \& Sargatal, J. (1994) Handbook of the Birds of the World, Volume 2. Lynx Edicions, Barcelona, Spain.

Ducatez, M.F., Tarnagda, Z., Tahita, M.C., Sow, A., De Landtsheer, S., LONDT, B.Z. et al. (2007) Genetic characterization of HPAI $\left(\mathrm{H}_{5} \mathrm{~N}_{1}\right)$ viruses from poultry and wild vultures, Burkina Faso. Emerging Infectious Diseases, 13, 611-613.

FA, J.E., Peres, C.A. \& Meeuwig, J. (2002) Bushmeat exploitation in tropical forests: an intercontinental comparison. Conservation Biology, 16, 232-237.

Fa, J.E., Seymour, S., Dupain, J., Amin, R., Albrechtsen, L. \& MaCDOnALD, D. (2006) Getting to grips with the magnitude of exploitation: bushmeat in the Cross-Sanaga rivers region, Nigeria and Cameroon. Biological Conservation, 129, 497-510.

Ferguson-Lees, J. \& Christie, D.A. (2001) Raptors of the World. Houghton Mifflin Harcourt, Boston, USA.

GiLl, D. (2010) Drivers of change in hunter offtake and hunting strategies in Sendje, Equatorial Guinea. MSc thesis. Imperial College, London, UK.

Griffiths, C.S., Barrowclough, G.F., Groth, J.G. \& Mertz, L.A. (2007) Phylogeny, diversity, and classification of the Accipitridae based on DNA sequences of the RAG-1 exon. Journal of Avian Biology, 38, 587-602.

Hiraldo, F., Blanco, J.C. \& Bustamante, J. (1991) Unspecialized exploitation of small carcasses by birds. Bird Study, 38, 200-207.

IUCN (2015) IUCN Red List of Threatened Species v. 2015.2. Http:// www.iucnredlist.org [accessed 2 April 2015].

Jenkins, A.R., Smallie, J.J. \& Diamond, M. (2010) Avian collisions with power lines: a global review of causes and mitigation with a South African perspective. Bird Conservation International, 20, 263-278.

Johnson, J.B. \& OMLAnd, K.S. (2004) Model selection in ecology and evolution. Trends in Ecology \& Evolution, 19, 101-108.

Juste, J., Fa, J.E., Del Val, J.P. \& Castroviejo, J. (1995) Market dynamics of bushmeat species in Equatorial Guinea. Journal of Applied Ecology, 32, 454-467.

Kane, A., Jackson, A.L., Ogada, D.L., Monadjem, A. \& McNally, L. (2014) Vultures acquire information on carcass location from scavenging eagles. Proceedings of the Royal Society B, 281, 20141072.

KeIth, J.O. \& BRUGgers, R.L. (1998) Review of hazards to raptors from pest control in Sahelian Africa. Journal of Raptor Research, 32, 151-158.

Kendall, C.J. (2013) Alternative strategies in avian scavengers: how subordinate species foil the despotic distribution. Behavioral Ecology and Sociobiology, 67, 383-393.

Lerner, H.R. \& Mindell, D.P. (2005) Phylogeny of eagles, Old World vultures, and other Accipitridae based on nuclear and mitochondrial DNA. Molecular Phylogenetics and Evolution, 37, 327-346.

Lindsey, P.A., Balme, G., Becker, M., BegG, C., Bento, C., Bocchino, C. et al. (2013) The bushmeat trade in African savannas: impacts, drivers, and possible solutions. Biological Conservation, 160, 80-96.

Mander, M., Diederichs, N., Ntuli, L., Mavundla, K., Williams, V. \& McKean, S. (2007) Survey of the Trade in Vultures for the Traditional Health Industry in South Africa. FutureWorks, Durban, South Africa. 
Martin, C. (1991) Forest conservation past and present. In The Rainforests of West Africa: Ecology, Threats, Conservation (ed. C. Martin), pp. 202-217. Birkhäuser, Basel, Germany.

Mundy, P., Butchart, D., Ledger, J. \& Piper, S. (1992) The Vultures of Africa. Acorn Books and Russel Friedman Books, Johannesburg, South Africa.

MURN, C. (2014) Observations of predatory behavior by white-headed vultures. Journal of Raptor Research, 48, 297-299.

NEW MARK, W.D. (2008) Isolation of African protected areas. Frontiers in Ecology and the Environment, 6, 321-328.

Nikolaus, G. (2001) Bird exploitation for traditional medicine in Nigeria. Malimbus, 23, 45-55.

Nikolaus, G. (2006) Where have the African vultures gone? Vulture News, 55, 65-67.

Nikolaus, G. (2011) The fetish culture in West Africa: an ancient tradition as a threat to endangered bird life? In Tropical Vertebrates in a Changing World (ed. K.L. Schuchmann), pp. 145-150. Zoologisches Forschungsmuseum Alexander Koenig, Bonn, Germany.

Nifforti, H.L. (1996) Preferences and present demand for bushmeat in north Cameroon: some implications for wildlife conservation. Environmental Conservation, 23, 149-155.

OFFTAKE (2014) Http://www.offtake.org [accessed 3 June 2015].

OGADA, D. (2014) The power of poison: pesticide poisoning of Africa's wildlife. Annals of the New York Academy of Sciences, 1322, 1-20.

OGADA, D.L. \& BuiJ, R. (2011) Large declines of the hooded vulture Necrosyrtes monachus across its African range. Ostrich, 82, 101-113.

Ogada, D., Shaw, P., Beyers, R.L., Buij, R., Murn, C., Thiollay, J. M. et al. (2015) Another continental vulture crisis: Africa's vultures collapsing toward extinction. Conservation Letters, http://dx.doi. org/10.1111/conl.12182.

Oкоuу о коuу , N.W. J. (2006) Savoirs locaux et outils modernes cynégétiques: développement de la filière commerciale de viande de brousse à Makokou (Gabon). PhD thesis. Université d'Orléans, France.

Oro, D., Margalida, A., Carrete, M., Heredia, R. \& Donázar, J A. (2008) Testing the goodness of supplementary feeding to enhance population viability in an endangered vulture. PLOS ONE, 3 (12), e4084.

Ortega, E., Mañosa, S., Margalida, A., Sánchez, R., Oria, J. \& GonZÁlez, L.M. (2009) A demographic description of the recovery of the Vulnerable Spanish imperial eagle Aquila adalberti. Oryx, 43, $113-121$.

Otieno, P.O., Lalah, J.O., Virani, M., Jondiko, I.O. \& Schramm, K.W. (2010) Carbofuran and its toxic metabolites provide forensic evidence for furadan exposure in vultures (Gyps africanus) in Kenya. Bulletin of Environmental Contamination and Toxicology, 84, 536-544.

R Development Core Team (2014) R: A Language and Environment for Statistical Computing. R Foundation for Statistical Computing, Vienna, Austria.

Rondeau, G. \& Thiollay, J.M. (2004) West African vulture decline. Vulture News, 51, 13-33.

SÆther, B.E. \& BAKKe, Ø. (2000) Avian life history variation and contribution of demographic traits to the population growth rate. Ecology, 81, 642-653.

SAIDU, Y. \& BUiJ, R. (2013) Traditional medicine trade in vulture parts in northern Nigeria. Vulture News, 65, 4-14.
Shimelis, A., Sande, E., Evans, S. \& Mundy, P. (2005) International Species Action Plan for the Lappet-faced vulture, Torgos tracheliotus. BirdLife International, Nairobi, Kenya and Royal Society for the Protection of Birds, Sandy, UK.

Shultz, S. (2002) Population density, breeding chronology and diet of crowned eagles Stephanoaetus coronatus in Tai National Park, Ivory Coast. Ibis, 144, 135-138.

Steyn, P. (1982) Birds of Prey of Southern Africa. David Philip Publishers, Cape Town, South Africa.

Thibault, M. \& Blaney, S. (2003) The oil industry as an underlying factor in the bushmeat crisis in Central Africa. Conservation Biology, $17,1807-1813$.

Thiollay, J.M. (1977) Distribution saisonnière des rapaces diurnes en Afrique occidentale. Oiseau Rev Fr Orn, 47, 253-285.

Thiollay, J.M. (2001) Long-term changes of raptor populations in northern Cameroon. Journal of Raptor Research, 35, 173-186.

Thiollay, J.M. (2006) The decline of raptors in West Africa: longterm assessment and the role of protected areas. Ibis, 148, 240-254.

White, F. (1983) The Vegetation of Africa: A Descriptive Memoir to Accompany the UNEXCO/AETFAT/UNSO Vegetation Map of Africa. UNESCO, Paris, France.

Whitfield, D.P., Fielding, A.H., McLeod, D.R.A. \&Haworth, P.F. (2004) Modelling the effects of persecution on the population dynamics of golden eagles in Scotland. Biological Conservation, 119, 319-333.

Whytock, R.C., Buij, R., Virani, M.Z. \& Morgan, B.J. (2014) Do large birds experience previously undetected levels of hunting pressure in the forests of Central and West Africa? Oryx. Http://dx. doi.org/10.1017/Soo30605314000064 [accessed 9 June 2015].

Whytock, R.C. \& Morgan, B.J. (2010) The commercial trade in bushmeat potentially threatens raptor populations in the Ebo forest, Cameroon. Gabar, 21, 1-7.

Wilkie, D.S. \& Carpenter, J.F. (1999) Bushmeat hunting in the Congo Basin: an assessment of impacts and options for mitigation. Biodiversity and Conservation, 8, 927-955.

Williams, V.L., Cunningham, A.B., Kemp, A.C. \& Bruyns, R.K. (2014) Risks to birds traded for African traditional medicine: a quantitative assessment. PLoS ONE, 9(8), e105397.

Zwarts, L., Bijlsma, R.G., van Der Kamp, J. \& Wymenga, E. (2009) Living on the Edge: Wetlands and Birds in a Changing Sahel. KNNV Publishing, Zeist, The Netherlands.

\section{Biographical sketches}

RALPH BUIJ studies relationships between land-use change, hunting, and protected area management and population dynamics of birds and mammals in West and Central Africa. Gerhard Nikola us is an ornithologist with many decades of experience in sub-Saharan Africa, and the author of Distribution Atlas of Sudan's Birds, with Notes on Habitat and Status. He performed most of the market surveys presented here. RовіN Wнутоск's research interests include investigating the decline of Afro-Palearctic migrants, and the conservation ecology of birds in the Lower and Upper Guinean forests. D ANIEL INGRAM is a conservation scientist and modeller investigating the exploitation of terrestrial species throughout the tropics. He is the manager of the OFFTAKE database. DARCY OGADA is a conservation biologist whose main focus is East African raptors and combating poisoning of wildlife. 